\title{
THERMAL DEGRADATION KINETICS OF TOTAL POLYPHENOLS, FLAVONOIDS, ANTHOCYANINS AND INDIVIDUAL ANTHOCYANINS IN TWO TYPES OF WILD BLACKBERRY JAMS
}

Milena Nikolić, Aleksandra Pavlović*, Milan Mitić, Snežana Mitić, Snežana Tošić, Emilija Pecev-Marinković, Jelena Mrmošanin

University of Niš, Faculty of Science and Mathematics, Department of Chemistry, Niš, Serbia

Fresh wild blackberries were processed into sugar and sugar-low jams at high temperatures $\left(90,95,100\right.$ and $\left.105^{\circ} \mathrm{C}\right)$. Total phenolic (TP), flavonoid (TF), anthocyanin (TA) contents and antioxidant activity, as well as the content of individual anthocyanins were significantly affected by the temperature, heating time and jam type, with the largest retention in the sugar-low jam prepared at $90^{\circ} \mathrm{C}$ for 5 minutes and with the largest decrease in the sugar jam prepared at $105^{\circ} \mathrm{C}$ for 30 minutes. Cyanidin3-rutinoside was found to be the most stable and cyanidin-3-malonylglucoside was found to be the least stable in sugar-low jam. In sugar jam, cyanidin-3-rutinoside and cyanidin-3-malonylglucoside have shown a relatively equable stability, while cyanidin-3-glucoside was the least stable. In the temperature interval from $90^{\circ} \mathrm{C}$ to 105 ${ }^{\circ} \mathrm{C}$, the degradation of total anthocyanins in both sugar and sugar-low jam types followed the first-order reaction, with activation energies (Ea) of $57.4 \mathrm{~kJ} / \mathrm{mol}$ and 48.0 $\mathrm{kJ} / \mathrm{mol}$, respectively. The half-life values $\left(\mathrm{t}_{1 / 2}\right)$ of total anthocyanins ranged from 6.6 to 15.9 minutes for the sugar jam and from 13.1 to 27.7 minutes for the sugar-low jam. The degradation of total anthocyanins is more susceptible to temperature elevation in the sugar jam compared to the sugar-low type.
(ORIGINAL SCIENTIFIC PAPER) UDC 547.973:664.858:582.712

Keywords: anthocyanins, degradation kinetics, blackberry, jam, total polyphenols, antioxidant activity

\section{Introduction}

Small colorful berry fruits (strawberries, raspberries, blackberries, black currants) represent an excellent source of nutrients such as anthocyanins, flavanols, phenolic acids, tannins. Among them, blackberries have a significant nutritional value, as they contain a high amount of anthocyanins [1-3]. Furthermore, health-beneficial cardioprotective, anti-inflammatory, anticancer and neuroprotective effects of anthocyanins are reported [4, 5].

Therefore, it is important to examine the changes which anthocyanins undergo during the preparation of food which is widely consumed, such as fruit juices, jams and jellies. The preparation of jam is one of the most common ways of preserving fruits for a longer period of time. However, anthocyanins are sensitive to the temperature rise, and their thermal degradation follows the first-order kinetic where the rate constant increases with the increase in temperature $[6,7]$.The retention of $79 \%$ of total anthocyanins in sugar and sugar free blueberry jams boiled for 1 minute has been observed [8]. On the other hand, Garcia-Viguera et al. [9] noticed a drastic anthocyanin loss of $81 \%$ in strawberry jams when being boiled longer than 15 minutes. According to Oancea and Calin [10], when fruits are brought to boil for 30 minutes, the jam processing diminishes the level of total anthocyanins in red raspberry and sweet cherry by approximately $66 \%$, and in blackberry and sour cherry by over $80 \%$.
But to the best of our knowledge, the influence of high temperatures on the content of total and individual anthocyanins during the blackberry jam preparation has not been researched comparatively. So, the aim of this research was to analyze the correlation between temperature, added sugar and total and individual anthocyanin content, as well as total anthocyanin degradation kinetic in sugar and sugar-low blackberry jams. In addition, total phenolic and flavonoid contents and antioxidant activity by DPPH assay were also determined.

\section{Materials and methods}

\section{Chemicals}

Trolox was purchased from Acros Organics (Morris Plains, New Jersey, USA). DPPH, gallic acid, (+)-catechin, (HPLC grade), saccharose and glucose were purchased from Sigma Aldrich (Steineheim, Germany). Cyanidin3-O-glucoside chloride (HPLC grade) was from ChromaDex (Irvine, CA, USA). Folin-Ciocalteu's phenol reagent, sodium hydroxide, sodium acetate, sodium nitrite, sodium carbonate, potassium chloride, aluminum chloride hexahydrate and hydrochloric acid were purchased from Merck® (Darmstadt, Germany). Ethanol ( $96 \%$ by vol.) and methanol (HPLC grade) was purchased from J.T. Baker

\footnotetext{
*Author address: Aleksandra Pavlović, University of Niš, Faculty of Science and Mathematics, Department of Chemistry, Višegradska 33, 18000 Niš Serbia

E-mail: aleksandra.pavlovic@pmf.edu.rs

The manuscript received: February, 07, 2018.

Paper accepted: March, 30, 2018.
} 
(Deventer, The Netherlands). Purified water (18 $\mathrm{M} \Omega \mathrm{cm})$, prepared by a MicroMed purification system (TKA Wasseraufbereitungssysteme $\mathrm{GmbH}$, Niederelbert, Germany) was used to prepare all samples and standards.

\section{Instruments}

An Agilent 8453 UV/Vis spectrophotometer (Agilent Technologies, Santa Clara, California, USA) was used for absorbance measurements and spectra recording, using optical cuvettes of $1 \mathrm{~cm}$ optical path. The $\mathrm{pH}$ measurements were made with Hanna instrument $\mathrm{pH}$-meter (Hanna Instruments, Smithfield, Rhode Island, USA) equipped with a glass electrode. The model 1200 (Agilent Technologies, Santa Clara, California, USA) was used for HPLC analysis. The analytical column was C18 Zorbax Eclipse

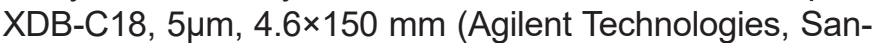
ta Clara, California, USA).

\section{Samples}

Wild blackberry samples were harvested in Southeastern Serbia (Babicka gora region), during August 2017. The amount of harvested berries was approximately $500 \mathrm{~g}$. Before the analysis, the samples (whole fresh fruits) were stored in the fridge at $-18^{\circ} \mathrm{C}$.

\section{Preparation of jams}

Frozen wild blackberry fruits were milled in the blender to obtained puree which was used for jam preparation. Flesh and seeds were not separated. Two types of jams (sugar and sugar-low) were prepared according to a slightly modified method described by de Moura et al. [11]. The sugar type implied $60 \%$ of fruit purée, $30 \%$ of saccharose, $9.8 \%$ of glucose and $0.2 \%$ of commercially available pectin for domestic use. The sugar-low type implied $94.2 \%$ of fruit purée, $5 \%$ of saccharose and $0.8 \%$ of commercially available pectin for domestic use.

The mixtures were heated to the temperatures of 90 , 95,100 and $105^{\circ} \mathrm{C}$ and stirred frequently in opened vessels. The temperature was registered using a laboratory thermometer and stabilized at the process temperature $\left( \pm 1^{\circ} \mathrm{C}\right)$. Once isothermal conditions were achieved, the samples were taken at different heating times: $5,10,15$, 20 and 30 minutes, and immediately cooled in cold water to stop further thermal degradation. The first sample was taken before the heating began $\left(\mathrm{c}_{0}\right)$. The analysis was done immediately.

\section{Extraction procedure}

The ultrasonic extractions of jam samples were performed at room temperature $\left(25^{\circ} \mathrm{C}\right)$ for 15 minute, three times. Briefly, $5.0000 \mathrm{~g} \pm 0.0001 \mathrm{~g}$ of each jam sample was weighed and mixed with $5 \mathrm{~mL}$ of acidified $(1 \% \mathrm{HCl})$ methanol. The flask with a sample was put into the ultrasonic bath and sonicated for $15 \mathrm{~min}$. The extract was filtered, and the clear supernatant was collected. The fractions from three times repeated extractions were collected and evaporated to dryness by rotary evaporation under the reduced pressure at $40^{\circ} \mathrm{C}$. Ultrapure water was added to $10 \mathrm{~mL}$ and these solutions were used for further analysis. The $\mathrm{pH}$ value of all samples was below 2 .

\section{HPLC analysis}

In order to identify and determine the individual anthocyanins content, Agilent-1200 series HPLC with the UV-Vis photodiode array detector (DAD) was used. The column was thermostated at $25^{\circ} \mathrm{C}$. After injecting $5 \mu \mathrm{L}$ of the sample, the separation was performed in an Agilent-Eclipse XDB C-18 4.6×150 mm column. The mobile phase consisted of aqueous $5 \%$ formic acid (eluent $A$ ) and $80 \%$ acetonitrile/5\% formic acid (eluent B). The elution program used was as follows: from 0 to $10 \mathrm{~min} 0 \% \mathrm{~B}$, from 10 to 28 min gradually increases $0-25 \%$, from 28 to $30 \mathrm{~min} 25 \% \mathrm{~B}$, from 30 to 35 min gradually increases $25-50 \%$ B, from 35 to 40 min gradually increases $50-80 \%$ $\mathrm{B}$, and finally for the last 5 min gradually decreases $80-0 \%$ B. The identification of individual compounds was based on the retention time and spectral data with those of the standard cyanidin-3-glucoside. Quantitative determination of individual anthocyanins in the samples was calculated using a calibration curve of cyanidin-3-glucoside. Triplicate measurements were taken, and data were presented as mean \pm standard deviation (SD).

Total polyphenolic content (TP)

Total polyphenols were determined according to the Folin-Ciocalteu procedure $[12,13]$ using gallic acid as a standard and expressing the results as gallic acid equivalents (GAE) per gram of jam samples (mg GAE/g). All measurements were performed in triplicate.

Total flavonoid content (TF)

The total flavonoid content was measured by the aluminum chloride spectrophotometric method [14]. Catechin was chosen as a standard and the results expressed as gram of catechin equivalents (CE) per gram of jam samples (mg CE/g). The levels of total flavonoid contents in jam extracts were determined in triplicate.

\section{Total anthocyanins (TA)}

The monomeric anthocyanin contents of the acidified methanol extracts were determined using the $\mathrm{pH}$-differential method [15]. The total anthocyanin content was calculated as milligram of cyanidin-3-glucoside equivalents per gram of the jam (mg cy-3-glu/g), using an extinction coefficient of $26.900 \mathrm{~L} / \mathrm{molcm}$ and the molecular weight of $449.2 \mathrm{~g} / \mathrm{mol}$.

\section{Antioxidative assay}

The free radical scavenging capacity was determined by DPPH method [16], which was slightly modified. The solution of DPPH $\left(1 \times 10^{-4} \mathrm{~mol} / \mathrm{L}\right)$ was prepared in methanol. $5.0 \mathrm{ml}$ of this solution and $100 \mu \mathrm{L}$ of the jam extract were mixed in $10 \mathrm{ml}$ volumetric flask and filled up with methanol to the mark. The discoloration of the DPPH radical was measured at $520 \mathrm{~nm}, 30 \mathrm{~min}$ after the reaction started. The Trolox calibration curve was plotted as a function of the decrease in absorbance of DPPH radical 
scavenging activity. The final results were expressed as milimoles of Trolox equivalents (TE) per gram of the jam sample (mmol TE/g).

\section{Results and discussion}

According to the final outcomes presented in Table 1, total polyphenolic (TP), total flavonoid (TF), total anthocyanin (TA) contents and antioxidant activity of the jam samples decreased in time and temperature-dependent manners but being more pronounced in sugar than in sugar-low jam at all applied temperatures.

A slight loss in TP, TF, TA and the antioxidant activity was observed after 5 minutes of heating in the temperature interval $105-90{ }^{\circ} \mathrm{C}$ with retention percentage yielding approximately $79.3-89.6 \%, 73.2-85.8 \%, 55.3-67.5 \%$ and $80.3-89.5 \%$ in sugar jam and $83.4-90.6 \%, 83.3-91.0 \%$, $84.5-96.5 \%$ and $87.7-91.7 \%$ in sugar-low jam samples.

Moderate to a significant loss in TP, TF, TA and antioxidant activity contents was noticed after 15 and 20 minutes of heating. After 20 minutes of heating, deviation from lin- earity regarding the contents of all examined compounds was observed in both jam types. The greatest loss in TP, TF, TA contents and antioxidant activity was noticed after 30 minutes of the thermal treatment at $105^{\circ} \mathrm{C}$, with retention percentage yielding $27.5 \%, 30.1 \%, 18.6 \%$ and $31.4 \%$ in sugar jam and $49.9 \%, 44.1 \%, 13.1$ and $64.8 \%$ in sugarlow jam, respectively.

The obtained results are in agreement with literature data. Namely, in the study of Rababah et al. [17] it was also reported that jam processing and storage during five months caused a decrease in total phenolic and anthocyanin contents, as well as a decrease in the antioxidant activity of strawberry, cherry, apricot, fig and orange jams. No influence of sugar addition was examined in the mentioned study. Garcia-Viguera et al. 1999 [18] have reported the loss up to $40 \%$ in the total anthocyanin content during the red raspberry jam preparation. According to Zhang et al. [19] the total anthocyanin content and antioxidant activity of blackberry juice reduced when the juice was being heated at 70,80 and $90^{\circ} \mathrm{C}$.

Table 1. Total phenolic (TP), total flavonoid (TF), total anthocyanin (TA) contents and antioxidant activity during processing of sugar and sugar-low blackberry jams ${ }^{a}$

\begin{tabular}{|c|c|c|c|c|c|c|c|c|c|}
\hline \multirow{2}{*}{$\begin{array}{c}\text { Temperature } \\
\left({ }^{\circ} \mathrm{C}\right)\end{array}$} & \multirow{2}{*}{$\begin{array}{l}\text { Time } \\
(\mathrm{min})\end{array}$} & \multicolumn{2}{|c|}{ TP (mg GAE/g) } & \multicolumn{2}{|c|}{ TF (mg CE/g) } & \multicolumn{2}{|c|}{ TA (mg cy-3-gly/g) } & \multicolumn{2}{|c|}{ DPPH (mmol TE/g) } \\
\hline & & Sugar & Sugar-low & Sugar & Sugar-low & Sugar & Sugar-low & Sugar & Sugar-low \\
\hline & & $3.31 \pm 0.01^{*}$ & $4.19 \pm 0.05^{*}$ & $0.203 \pm 0.002$ & $0.247 \pm 0.003^{*}$ & $0.953 \pm 0.002^{*}$ & $1.02 \pm 0.01^{*}$ & $0.426 \pm 0.005$ & $0.326 \pm 0.001^{*}$ \\
\hline & 5 & $2.965 \pm 0.002$ & $3.80 \pm 0.07$ & $0.175 \pm 0.005$ & $0.224 \pm 0.003$ & $0.643 \pm 0.001$ & $0.981 \pm 0.003$ & $0.38 \pm 0.02$ & $0.299 \pm 0.002$ \\
\hline & 10 & $2.59 \pm 0.03$ & $3.66 \pm 0.01$ & $0.164 \pm 0.003$ & $0.213 \pm 0.001$ & $0.612 \pm 0.001$ & $0.903 \pm 0.001$ & $0.337 \pm 0.008$ & $0.296 \pm 0.003$ \\
\hline & 15 & $2.33 \pm 0.01$ & $3.38 \pm 0.05$ & $0.148 \pm 0.001$ & $0.199 \pm 0.005$ & $0.586 \pm 0.002$ & $0.866 \pm 0.004$ & $0.307 \pm 0.000$ & $0.29 \pm 0.01$ \\
\hline & 20 & $1.94 \pm 0.05$ & $3.218 \pm 0.004$ & $0.14 \pm 0.02$ & $0.180 \pm 0.006$ & $0.543 \pm 0.001$ & $0.767 \pm 0.003$ & $0.263 \pm 0.006$ & $0.281 \pm 0.002$ \\
\hline & 30 & $1.55 \pm 0.01$ & $2.94 \pm 0.03$ & $0.131 \pm 0.005$ & $0.17 \pm 0.01$ & $0.474 \pm 0.002$ & $0.68 \pm 0.04$ & $0.210 \pm 0.005$ & $0.27 \pm 0.01$ \\
\hline & 5 & $2.89 \pm 0.03$ & $3.75 \pm 0.05$ & $0.169 \pm 0.001$ & $0.22 \pm 0.00$ & $0.615 \pm 0.003$ & $0.946 \pm 0.002$ & $0.37 \pm 0.01$ & $0.296 \pm 0.003$ \\
\hline & 10 & $2.435 \pm 0.002$ & $3.4178 \pm 0.02$ & $0.151 \pm 0.003$ & $0.197 \pm 0.003$ & $0.564 \pm 0.003$ & $0.852 \pm 0.001$ & $0.314 \pm 0.005$ & $0.287 \pm 0.001$ \\
\hline & 15 & $1.91 \pm 0.05$ & $3.06 \pm 0.03$ & $0.136 \pm 0.03$ & $0.18 \pm 0.02$ & $0.461 \pm 0.002$ & $0.781 \pm 0.002$ & $0.28 \pm 0.09$ & $0.283 \pm 0.001$ \\
\hline & 20 & $1.65 \pm 0.01$ & $2.845 \pm 0.004$ & $0.120 \pm 0.002$ & $0.166 \pm 0.007$ & $0.435 \pm 0.000$ & $0.68 \pm 0.01$ & $0.233 \pm 0.003$ & $0.272 \pm 0.003$ \\
\hline & 30 & $1.315 \pm 0.004$ & $2.72 \pm 0.01$ & $0.110 \pm 0.005$ & $0.143 \pm 0.003$ & $0.388 \pm 0.002$ & $0.587 \pm 0.003$ & $0.178 \pm 0.001$ & $0.257 \pm 0.01$ \\
\hline & 5 & $2.73 \pm 0.03$ & $3.58 \pm 0.01$ & $0.16 \pm 0.02$ & $0.21 \pm 0.01$ & $0.573 \pm 0.003$ & $0.904 \pm 0.004$ & $0.357 \pm 0.003$ & $0.290 \pm 0.002$ \\
\hline & 10 & $2.09 \pm 0.05$ & $3.15 \pm 0.03$ & $0.129 \pm 0.002$ & $0.184 \pm 0.05$ & $0.470 \pm 0.001$ & $0.784 \pm 0.002$ & $0.3 \pm 0.0000$ & $0.280 \pm 0.002$ \\
\hline & 15 & $1.45 \pm 0.03$ & $2.86 \pm 0.03$ & $0.117 \pm 0.003$ & $0.165 \pm 0.002$ & $0.354 \pm 0.003$ & $0.684 \pm 0.002$ & $0.244 \pm 0.004$ & $0.271 \pm 0.005$ \\
\hline & 20 & $1.35 \pm 0.05$ & $2.64 \pm 0.02$ & $0.095 \pm 0.000$ & $0.148 \pm 0.001$ & $0.320 \pm 0.002$ & $0.631 \pm 0.001$ & $0.206 \pm 0.002$ & $0.26 \pm 0.01$ \\
\hline & 30 & $1.10 \pm 0.07$ & $2.29 \pm 0.03$ & $0.076 \pm 0.002$ & $0.13 \pm 0.02$ & $0.271 \pm 0.001$ & $0.54 \pm 0.01$ & $0.2 \pm 0.0000$ & $0.236 \pm 0.003$ \\
\hline & 5 & $2.62 \pm 0.01$ & $3.50 \pm 0.07$ & $0.15 \pm 0.01$ & $0.205 \pm 0.005$ & $0.527 \pm 0.003$ & $0.859 \pm 0.002$ & $0.342 \pm 0.003$ & $0.286 \pm 0.005$ \\
\hline & 10 & $1.494 \pm 0.03$ & $2.97 \pm 0.02$ & $0.112 \pm 0.007$ & $0.177 \pm 0.003$ & $0.369 \pm 0.002$ & $0.685 \pm 0.002$ & $0.247 \pm 0.007$ & $0.268 \pm 0.001$ \\
\hline & 15 & $1.103 \pm 0.002$ & $2.62 \pm 0.03$ & $0.095 \pm 0.005$ & $0.15 \pm 0.03$ & $0.230 \pm 0.003$ & $0.580 \pm 0.003$ & $0.200 \pm 0.003$ & $0.247 \pm 0.002$ \\
\hline & 20 & $1.03 \pm 0.04$ & $2.32 \pm 0.01$ & $0.08 \pm 0.02$ & $0.125 \pm 0.002$ & $0.203 \pm 0.003$ & $0.51 \pm 0.01$ & $0.164 \pm 0.003$ & $0.241 \pm 0.002$ \\
\hline & 30 & $0.91 \pm 0.01$ & $2.09 \pm 0.05$ & $0.061 \pm 0.001$ & $0.109 \pm 0.002$ & $0.177 \pm 0.002$ & $0.437 \pm 0.002$ & $0.134 \pm 0.004$ & $0.211 \pm 0.005$ \\
\hline
\end{tabular}

${ }^{*} \mathrm{C}_{0}$-initial concentrations

HPLC analysis of individual anthocyanins

The results regarding the changes in the content of individual anthocyanins are represented in Table 2.

Three peaks were identified: cyanidin-3-glucoside, and two derivates of cyanidin, for what we believe to represent cyanidin-3-rutinoside and cyanidin-3-malonylglucoside (Fig. 1), since the order of appearance is in accordance with the literature data [1], where the same anthocyanins were identified along with cyanidin-3-xyloside and an unidentified acylated derivative of cyanidin-3-glucoside [1, 20].

In our case, cyanidin-3-glucoside was the most abundant, followed by cyanidin-3-rutinoside and cyanidin3-malonylglucoside, which is also in accordance with previously reported data [1]. Lower contents of all individual anthocyanins were noted in sugar jam. The preparation of jam of both types at $90{ }^{\circ} \mathrm{C}$ resulted in greater retention 
of individual anthocyanins, comparing to the preparation of jams at higher temperatures. Adams et al. proposed hydrolysis of sugar moiety and aglycone formation as the initial degradation step possibly due to the formation of cyclic adducts [21]. The same authors assumed the an- thocyanin decomposition upon heating into a chalcone structure, which further transformed into a coumarin glucoside derivative with the loss of the B-ring.

Table 2. Content of individual anthocyanins in sugar and sugar-low blackberry jams during processing (mg/kg)a

\begin{tabular}{|c|c|c|c|c|c|c|c|}
\hline \multirow{2}{*}{$\begin{array}{l}\text { Temperature } \\
\left({ }^{\circ} \mathrm{C}\right)\end{array}$} & \multirow{2}{*}{$\begin{array}{l}\text { Time } \\
(\min )\end{array}$} & \multicolumn{2}{|c|}{ Cyanidin-3-glucoside } & \multicolumn{2}{|c|}{ Cyanidin-3-rutinoside } & \multicolumn{2}{|c|}{ Cyanidin-3-malonylglucoside } \\
\hline & & Sugar & Sugar-low & Sugar & Sugar-low & Sugar & Sugar-low \\
\hline & & $449.30 \pm 0.04^{*}$ & $550.0 \pm 0.1^{*}$ & $28.99 \pm 0.04^{*}$ & $35.01 \pm 0.05^{*}$ & $14.82 \pm 0.06^{*}$ & $17.87 \pm 0.05^{*}$ \\
\hline & 5 & $250.53 \pm 0.01$ & $462.43 \pm 0.02$ & $22.25 \pm 0.05$ & $32.13 \pm 0.08$ & $11.5 \pm 0.1$ & $13.32 \pm 0.07$ \\
\hline & 10 & $246.05 \pm 0.02$ & $391.29 \pm 0.06$ & $18.55 \pm 0.06$ & $27.4 \pm 0.3$ & $9.41 \pm 0.02$ & $10.85 \pm 0.02$ \\
\hline & 15 & $221.7 \pm 0.3$ & $356.75 \pm 0.01$ & $17.88 \pm 0.02$ & $25.17 \pm 0.02$ & $8.91 \pm 0.05$ & $9.69 \pm 0.02$ \\
\hline & 20 & $218.08 \pm 0.05$ & $350.32 \pm 0.07$ & $15.25 \pm 0.04$ & $23.7 \pm 0.1$ & $8.27 \pm 0.05$ & $8.68 \pm 0.03$ \\
\hline & 30 & $178.37 \pm 0.01$ & $327.18 \pm 0.06$ & $12.39 \pm 0.05$ & $21.57 \pm 0.05$ & $7.5 \pm 0.1$ & $8.49 \pm 0.04$ \\
\hline & 5 & $224.01 \pm 0.02$ & $367.51 \pm 0.02$ & $17.7 \pm 0.1$ & $25.57 \pm 0.01$ & $9.47 \pm 0.02$ & $11.58 \pm 0.01$ \\
\hline & 10 & $223.28 \pm 0.01$ & $358.134 \pm 0.005$ & $15.82 \pm 0.02$ & $23.99 \pm 0.06$ & $8.51 \pm 0.04$ & $9.808 \pm 0.005$ \\
\hline & 15 & $201.35 \pm 0.05$ & $342.89 \pm 0.04$ & $14.30 \pm 0.06$ & $22.19 \pm 0.07$ & $7.86 \pm 0.05$ & $9.61 \pm 0.07$ \\
\hline & 20 & $166.06 \pm 0.02$ & $332.05 \pm 0.07$ & $11.43 \pm 0.04$ & $21.34 \pm 0.02$ & $6.20 \pm 0.01$ & $9.49 \pm 0.06$ \\
\hline & 30 & $147.1 \pm 0.2$ & $249.6 \pm 0.1$ & $11.26 \pm 0.07$ & $19.4 \pm 0.3$ & $5.343 \pm 0.003$ & $7.24 \pm 0.08$ \\
\hline & 5 & $203.09 \pm 0.07$ & $245.01 \pm 0.02$ & $14.5 \pm 0.3$ & $19.40 \pm 0.07$ & $7.67 \pm 0.04$ & $8.11 \pm 0.02$ \\
\hline & 10 & $189.6 \pm 0.4$ & $212.65 \pm 0.01$ & $13.68 \pm 0.05$ & $17.72 \pm 0.04$ & $7.34 \pm 0.02$ & $6.82 \pm 0.08$ \\
\hline & 15 & $183.89 \pm 0.01$ & $208.67 \pm 0.01$ & $12.31 \pm 0.06$ & $15.33 \pm 0.01$ & $6.34 \pm 0.07$ & $6.43 \pm 0.05$ \\
\hline & 20 & $153.41 \pm 0.05$ & $202.9 \pm 0.2$ & $11.39 \pm 0.07$ & $13.45 \pm 0.06$ & $6.1 \pm 0.2$ & $6.22 \pm 0.01$ \\
\hline & 30 & $139.52 \pm 0.02$ & $192.07 \pm 0.05$ & $10.19 \pm 0.06$ & $12.27 \pm 0.04$ & $5.18 \pm 0.05$ & $5.42 \pm 0.06$ \\
\hline & 5 & $113.37 \pm 0.01$ & $222.64 \pm 0.04$ & $8.64 \pm 0.01$ & $16.145 \pm 0.002$ & $4.91 \pm 0.01$ & $7.02 \pm 0.04$ \\
\hline & 10 & $97.3 \pm 0.3$ & $205.77 \pm 0.02$ & $6.43 \pm 0.01$ & $14.76 \pm 0.08$ & $4.22 \pm 0.05$ & $5.01 \pm 0.02$ \\
\hline & 15 & $90.02 \pm 0.01$ & $199.11 \pm 0.06$ & $6.15 \pm 0.07$ & $13.74 \pm 0.02$ & $3.97 \pm 0.07$ & $4.720 \pm 0.005$ \\
\hline & 20 & $63.38 \pm 0.04$ & $180.94 \pm 0.01$ & $4.39 \pm 0.02$ & $12.98 \pm 0.05$ & $2.5 \pm 0.1$ & $4.35 \pm 0.01$ \\
\hline & 30 & $48.33 \pm 0.05$ & $168.52 \pm 0.3$ & $3.92 \pm 0.06$ & $11.27 \pm 0.01$ & $2.07 \pm 0.01$ & $3.68 \pm 0.06$ \\
\hline
\end{tabular}

${ }^{*} \mathrm{C}_{0}$-initial concentrations

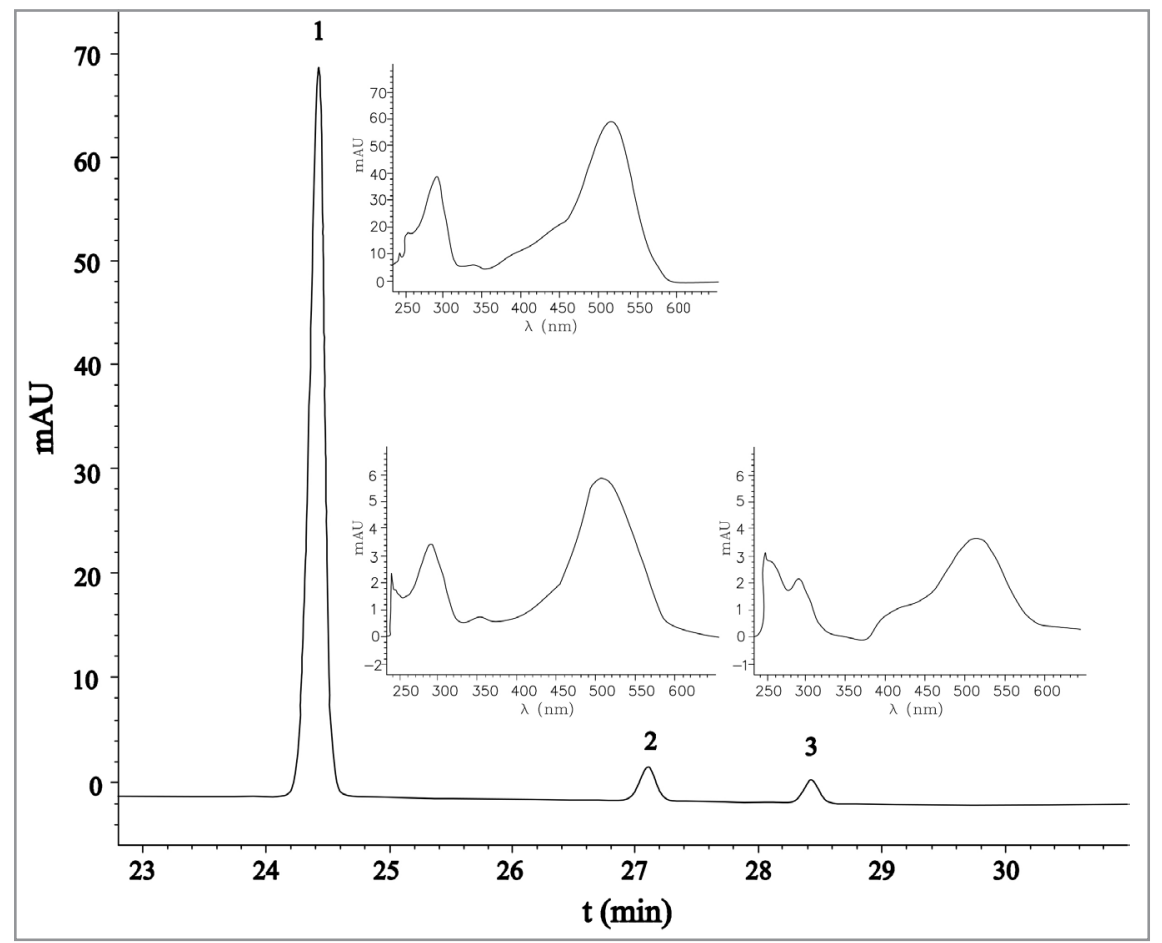

Figure 1. HPLC chromatogram and UV/Vis spectra of identified anthocyanins in the blackberry jam sample. The labels refer to the following: (1) cyanidin-3-glucoside; (2) cyanidin-3-rutinoside; (3) cyanidin-3-malonylglucoside; 
In sugar-low jam, a minor loss in cyanidin-3-glucoside, cyanidin-3-rutinoside and cyanidin-3-malonylglucoside contents was noticed after 5 minutes of heating at $90{ }^{\circ} \mathrm{C}$, with retention percentages yielding $84.1 \%, 91.8 \%$ and $74.5 \%$. Heating at $105{ }^{\circ} \mathrm{C}$ for 30 minutes caused a severe loss in the contents of all identified anthocyanins, with retention percentages of cyanidin-3-glucoside, cyanidin-3-rutinoside and cyanidin-3-malonylglucoside yielding $30.6 \%, 32.2 \%$ and $22.6 \%$, respectively.

Evidently, cyanidin-3-rutinoside was found to be the most stable, followed by cyanidin-3-glucoside and cyanidin-3-malonylglucoside. These results are in agreement with literature data since a greater loss of cyanidin-3-malonylglucoside $(46 \%)$ was noticed than that of cyanidin-3-glucoside (39\%) during blanching of tropical highland blackberry [20]. The results of the same study showed that cyanidin-3-glucoside was more stable than cyanidin-3-malonylglucoside during storage at $5{ }^{\circ} \mathrm{C}$ and at $30^{\circ} \mathrm{C}$. Zhang et al. [19] also confirmed greater stability of cyanidin-3-glucoside than of cyanidin-3-malonylglucoside in blackberry juice when being heated at 70,80 and $90{ }^{\circ} \mathrm{C}$. It has also been reported that cyanidin-3-rutinoside degraded less than cyanidin-3-glucoside during a combined heat-pressure treatment [22] and in acidified aqueous solutions at $100{ }^{\circ} \mathrm{C}$, in both aerobic and anaerobic conditions [21]. Lower thermal stability of cyanidin-3-malonylglucoside (comparing to glucoside and rutinoside) may be a consequence of the place of glycosylation and the presence of acylated substituents [23]. However, cyanidin-3-malonylglucoside may degrade by losing the malonyl moiety and forming cyanidin-3-glucoside, so the real degradation rate of cyanidin-3-glucoside may be masked [20], which must be taken into consideration when interpreting these results.

The preparation of the sugar jam at $90{ }^{\circ} \mathrm{C}$ for $5 \mathrm{~min}$ resulted in retaining $55.8 \%$ of cyanidin-3-glucoside, $76.9 \%$ of cyanidin-3-rutinoside and $77.3 \%$ of cyanidin3-malonylglucoside. Heating at $105{ }^{\circ} \mathrm{C}$ for $30 \mathrm{~min}$ had a devastating effect on the contents of all three anthocyanins, causing retention of only $10.8 \%, 12.9 \%$ and $13.9 \%$ of cyanidin-3-glucoside, cyanidin-3-rutinoside and cyanidin-3-malonylglucoside, respectively. In this case, cyanidin-3-rutinoside and cyanidin-3-malonylglucoside exhibited relatively equable stability, with slightly higher retention of cyanidin-3-malonylglucoside, while cyanidin3 -glucoside was the least stable. The conditions in sugar jam $(\mathrm{pH}<2,30 \%$ of saccharose) were probably favorable for creating furfural and its derivatives. According to literature data, degradation compounds derived from sugars are furfural and 5-hydroxymethylfurfural [24] and were proven to be responsible for the highest degradation of anthocyanins when added to the blackberry anthocyanin buffer solution at acidic conditions [25]. So, the higher retention of cyanidin-3-malonylglucoside comparing to cyanidin-3-glucoside and cyanidin-3-rutinoside can be explained by the fact that acyl groups generate steric hindrance effects for the possible ion attack on anthocyanins [26].

\section{Degradation kinetic of anthocyanins}

Linear regression confirmed that the degradation of total anthocyanins in both sugar and sugar-low jam samples was followed by the first-order reaction (Fig. 1 and 2 ). In this case, the first-order reaction can generally be expressed using Eq. (1) [27, 28] where $\mathrm{c}$ is the anthocyanin concentration at time $t, c_{0}$ is the initial anthocyanins concentration $(\mathrm{mg} / \mathrm{g})$, $\mathrm{t}$ is the treatment time $(\mathrm{min})$ and $\mathrm{k}$ is the first-order degradation rate constant $\left(\mathrm{min}^{-1}\right)$.

$c=c_{0} \cdot \exp (-k \cdot t)$

The half-lives $\left(t_{1 / 2}\right)$ of anthocyanins were calculated by Eq. (2):

$t_{1 / 2}=-\frac{\ln (0.5)}{k}=\frac{0.693}{k}$

The temperature-dependence degradation rate constant was represented by the Arrhenius equation (3):

$k=k_{0} \cdot e^{-E a / R T}$

where $k_{0}$ is the frequency factor (per min), Ea is the activation energy $(\mathrm{kJ} / \mathrm{mol}), \mathrm{R}$ is the universal gas constant $(8.314 \mathrm{~J} / \mathrm{molK})$ and $\mathrm{T}$ is the absolute temperature $(\mathrm{K})$.

The effect of the heating temperature on the anthocyanin degradation rate is shown in Fig. 2 and Fig. 3, and the kinetic parameters are given in Table 3 .

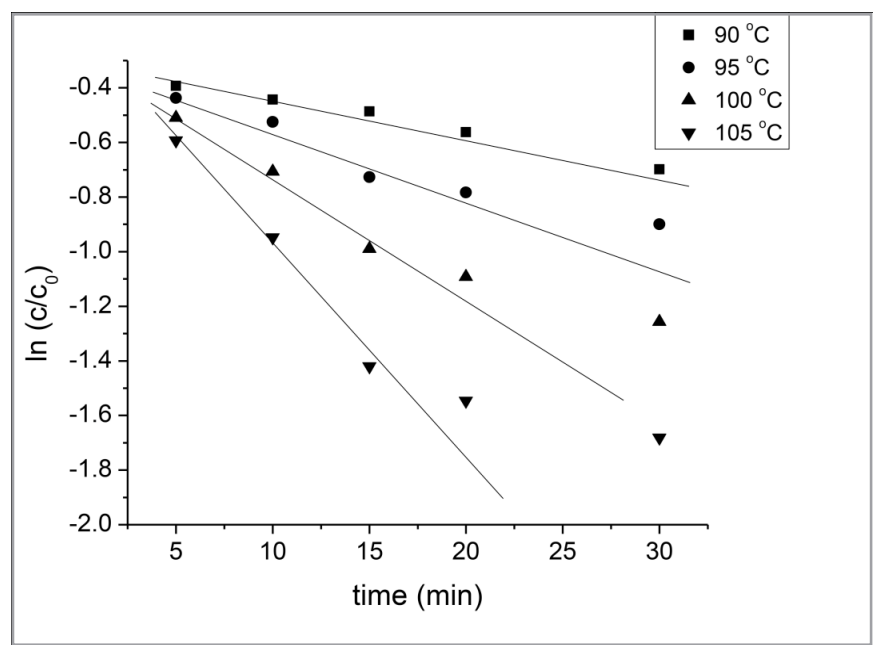

Figure 2. Degradation of total anthocyanins in wild blackberry sugar jam

Table 3. Effect of heating on the $k, t_{1 / 2}$ and Ea values of total anthocyanins degradation in sugar and sugar-low blackberry jams

\begin{tabular}{ccccc} 
Temperature $\left({ }^{\circ} \mathrm{C}\right)$ & $\begin{array}{c}\mathrm{k} \times 10^{-2} \\
\left(\mathrm{~min}^{-1}\right)\end{array}$ & $\mathrm{R}^{2}$ & $\begin{array}{c}\mathrm{t} 1 / 2 \\
(\mathrm{~min})\end{array}$ & $\begin{array}{c}\mathrm{Ea} \\
(\mathrm{kJ} / \mathrm{mol})\end{array}$ \\
\hline 90 & $4.4 \pm 0.2$ & 0.9868 & 15.9 & \\
95 & $5.6 \pm 0.1$ & 0.9077 & 12.3 & 57.4 \\
100 & $7.9 \pm 0.2$ & 0.9009 & 8.8 & \\
105 & $10.5 \pm 0.5$ & 0.9386 & 6.6 & \\
& \multicolumn{5}{c}{ Sugar-low jam } \\
Temperature $\left({ }^{\circ} \mathrm{C}\right)$ & $\mathrm{k} \times 10^{-2}$ & & $\mathrm{t}_{1 / 2}$ & $\mathrm{Ea}$ \\
$\left(\mathrm{min}^{-1}\right)$ & $\mathrm{R}^{2}$ & $(\mathrm{~min})$ & $(\mathrm{kJ} / \mathrm{mol})$ \\
\hline 90 & $2.5 \pm 0.4$ & 0.9813 & 27.7 & \\
95 & $3.4 \pm 0.2$ & 0.9891 & 20.2 & 48.0 \\
100 & $3.9 \pm 0.3$ & 0.9649 & 17.6 & \\
105 & $5.3 \pm 0.5$ & 0.9256 & 13.1 & \\
\hline
\end{tabular}




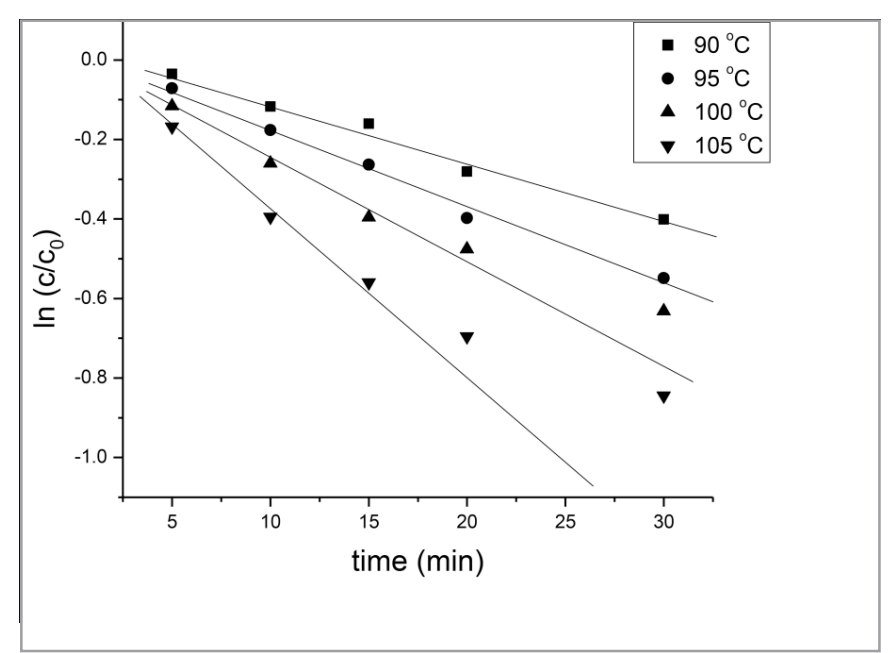

Figure 3. Degradation of total anthocyanins in wild blackberry sugar-low jam

The Arrhenius equation was used to describe the temperature dependence of the degradation rate constants. The temperature-dependent rate constant obeyed the Arrhenius relationship (Eq. (3)) and the Arrhenius plot is shown in Fig. 4.

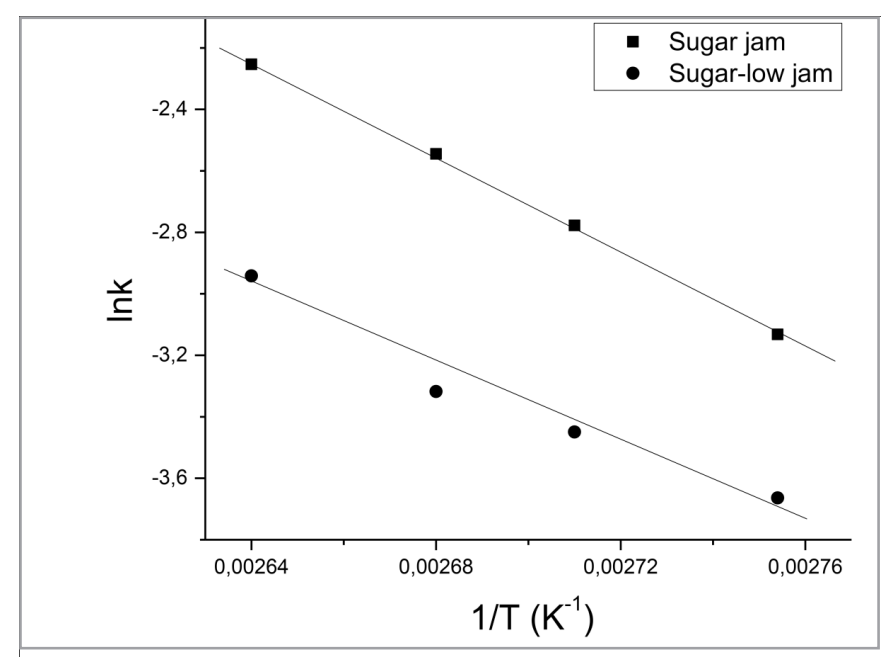

Figure 4. The Arrhenius plot for degradation of total anthocyanins in wild blackberry jam samples

The high $\mathrm{R}^{2}$ values obtained from Arrhenius plot confirm that the degradation increased with the increased temperature and time $\left(0.9009<R^{2}<0.9868\right)$. Therefore, the percentage of retention of anthocyanins strongly depends on the heating temperature and was ranged from $49.8 \%$ to $67.5 \%$ at $90{ }^{\circ} \mathrm{C}$, from $40.7 \%$ to $64.6 \%$ at $95{ }^{\circ} \mathrm{C}$, from $28.5 \%$ to $60.1 \%$ at $100{ }^{\circ} \mathrm{C}$ and from $18.6 \%$ to $55.3 \%$ at $105{ }^{\circ} \mathrm{C}$ in sugar jam. Total anthocyanins showed greater resistance towards high temperatures exposure in sugar-low jam, yielding from $66.9 \%$ to $96.5 \%$ at $90{ }^{\circ} \mathrm{C}$, from $57.8 \%$ to $93.1 \%$ at $95{ }^{\circ} \mathrm{C}$, from $53.2 \%$ to $89.1 \%$ at $100{ }^{\circ} \mathrm{C}$ and from $42.9 \%$ to $84.5 \%$ at $105^{\circ} \mathrm{C}$.

A larger amount of sugar in the sugar jam resulted in twice as higher degradation rate constants and approximately twice as lower half-lives comparing to the sugar- low jam at all applied temperatures. The $\mathrm{k}$ values ranged from $4.4 \times 10^{-2}$ to $10.5 \times 10^{-2} \mathrm{~min}^{-1}$ for the sugar jam and from $2.5 \times 10^{-2}$ to $5.3 \times 10^{-2} \mathrm{~min}^{-1}$ for the sugar-low jam. The $t_{1 / 2}$ values ranged from 15.9 to 6.6 minutes for the sugar jam and from 27.7 to 13.1 minutes for the sugar-low jam at $90{ }^{\circ} \mathrm{C}, 95^{\circ} \mathrm{C}, 100{ }^{\circ} \mathrm{C}$ and $105^{\circ} \mathrm{C}$, respectively. The obtained results are comparable with the ones regarding the anthocyanin degradation in the blood orange at 90 ${ }^{\circ} \mathrm{C}\left(\mathrm{k}=3.2 \times 10^{-2} \mathrm{~min}^{-1}\right.$ and $\left.\mathrm{t}_{1 / 2}=24 \mathrm{~min}\right)$ [27], but the influence of higher temperatures was not investigated in the mentioned study. The $k$ values on degradation kinetics of anthocyanins for $8.90^{\circ}$ Brix blackberry juice were found to be lower $\left(0.69-3.94 \times 10^{-2} \mathrm{~min}^{-1}\right)$, but lower temperatures were applied $\left(60-90^{\circ} \mathrm{C}\right)$ [29].

The value of the activation energy was $48.0 \mathrm{~kJ} / \mathrm{mol}$ and $57.4 \mathrm{~kJ} / \mathrm{mol}$ for sugar-low and sugar jam, respectively. This finding implies that the degradation of anthocyanins is more susceptible to the temperature elevation in the sugar jam. These values are in agreement with the results on degradation kinetics of anthocyanins for 8.90 ${ }^{\circ}$ Brix blackberry juice $(58.95 \mathrm{~kJ} / \mathrm{mol})$ [29] and with the results on thermal degradation of anthocyanins in soft drink mediums of elderberry juice and blackcurrant pomace extracts (56 kJ/mol and $50 \mathrm{~kJ} / \mathrm{mol}$ ) [30].

In general, the obtained results are in agreement with the result of the study of de Moura et al. [11], where it was found that the reduction in the amounts of anthocyanin compounds was greater in the traditional jam. Nikkhah et al. [31] reported a protective effect of sucrose in the concentration of $20 \%$ on mulberry and strawberry anthocyanins, but with higher concentrations this effect decreased. The research of de Rosso and Mercandante [32] has shown that the addition of sugars had a negative effect on the stability of anthocyanins from tropical fruits. Our results are also in accordance with the pioneering work of Meschter [33], where the ability of some sugars and sugar degradation products to increase the rate of strawberry pigment loss was demonstrated.

\section{Conclusion}

Our research showed that significant changes occur in TP, TF, TA and the antioxidant activity when blackberry fruits are processed into sugar and sugar-low jams. Individual anthocyanins are also notably affected by heating and a sugar amount. Thermal degradation of blackberry anthocyanins followed the first-order reaction kinetic. Higher retention of all analyzed compounds was accomplished in the sugar-low jam, at lower temperatures and a shorter heating time.

\section{Acknowledgements}

This research was supported by the Serbian Ministry of Education, Science and Technological Development, grant numbers 172047 and 41018 . The authors are grateful for the financial support provided by this Ministry. 


\section{References}

[1] H-J. Fang-Chiang, R.E. Wrolstad, Anthocyanin pigment composition of blackberries, Journal of Food Science, 70 (3) (2005) C198-C202.

[2] J. Reyes-Carmona, G.G. Yousef, R.A. Martinez-Peniche, M.A. Lila, Antioxidant Capacity of Fruit Extracts of Blackberry (Rubus sp.) Produced in Different Climatic Regions, Journal of Food Science, 70 (7) (2005) S497-S503.

[3] J. Ivanovic, V. Tadic, S. Dimitrijevic, M. Stamenic, S. Petrovic, I. Zizovic, Antioxidant properties of the anthocyanin-containing ultrasonic extract from blackberry cultivar „Čačanska Bestrna”, Industrial Crops and Products, 53 (2014) 274- 281.

[4] C.S. Bowen-Forbes, Y. Zhang, M.G. Nair, Anthocyanin content, antioxidant, anti-inflammatory and anticancer properties of blackberry and raspberry fruits, Journal of Food Composition and Analysis, 23 (6) (2010) 554-560.

[5] L. Tavares, I. Figueira, D. Macedo, G.J. McDougall, M. C. Leitão, H.L.A. Vieira, D. Stewart, P.M. Alves, R.B Ferreira, C.N. Santos, Neuroprotective effect of blackberry (Rubus sp.) polyphenols is potentiated after simulated gastrointestinal digestion, Food Chemistry, 131 (4) (2012) 1443-1452.

[6] A. Patras, N.P. Brunton, B. K. Tiwari, F. Butler, Stability and degradation kinetics of bioactive compounds and colour in strawberry jam during storage, Food and Bioprocess Technology, 4 (7) (2011) 1245-1252.

[7] C.P. Kechinski, P.V.R. Guimarâes, C.P.Z. Noreña, I.C. Tessaro, L.D.F. Marczak, Degradation kinetics of anthocyanin in blueberry juice during thermal treatment, Journal of Food Science, 75 (2) (2010) 173-176.

[8] L.R. Howard, C. Castrodale, C. Brownmiller, A. Mauromoustakos, Jam processing and storage effects on blueberry polyphenolics and antioxidant capacity, Journal of Agricultural and Food Chemistry, 58 (7)(2010) 40224029.

[9] C. García-Viguera, P. Zafrilla, F.A Tomás-Barberán, Influence of processing and storage conditions in strawberry jam color, Food Science and Technology International, 5 (6) (1999) 487-492.

[10] S. Oancea, F. Calin, Changes in total phenolics and anthocyanins during blackberry, raspberry and cherry jam processing and storage, Romanian Biotechnological Letters, 21 (1) (2016) 11232-11237.

[11] S.C.S.R.de Moura, P.E. da Rocha Tavares, S.P.M. Germer, A.L.A.C. Nisida, A.B. Alves, A.S. Kanaan, Degradation kinetics of anthocyanin of traditional and lowsugar blackberry jam, Food and Bioprocess Technology, 5 (6) (2012) 2488-2496.

[12] V.L. Singleton, R. Orthofer, R.M. LamuelaRaventos,Analysis of total phenols and other oxidation substrates and antioxidants by means of Folinciocalteureagent, Methods in Enzymology, 299 (1999) 152-178.

[13] P. Stratil, B. Klejdus, V. Kuban, Determination of total content of phenolic compounds and their antioxidant activity in vegetables-evaluation of spectrophotometric methods, Journal of Agricultural and Food Chemistry, 54 (3) (2006) 607-616.

[14] J. Zhishen, T. Mengcheng, W. Jianming, The determination of flavonoids content in mulberry and scavenging effect on superoxide radicals, Food Chemistry, 64 (4) (1999)555-
559.

[15] M.M. Guisti, R.E. Wrolstad, Characterization and measurement of anthocyanins by UV-visible spectroscopy, Current Protocols in Food Analytical Chemistry, (2001) F1.2.1-F1.2.13.

[16] W. Brand-Williams, M.E., Cuvelier, C. Berset, Use of a free radical method to evaluate antioxidant activity, Lebensmittel-Wissenschaft \& Technologie, 28 (1) (1999) 25-30.

[17] T.M. Rababah, M.A. Al-Mahasneh, I. Kilani, W. Yang, M.N. Alhamad, K. Ereifej, M. Al-u'datt, Effect of jam processing and storage on total phenolics, antioxidant activity and anthocyanins of different fruits, Journal of the Science of Food and Agriculture, 91 (6) (2011) 1096-1102.

[18] C. García-Viguera, P. Zafrilla, F. Artes, F. Romero, P. Abellán, F.A Tomás-Barberán, Colour and anthocyanin stability of red raspberry jam, Journal of the Science of Food and Agriculture, 78 (4) (1998) 565-573.

[19] L. Zhang, J. Zhou, H. Liu, M.A. Khan, K. Huang, Z. Gu, Compositions of anthocyanins in blackberry juice and their thermal degradation in relation to antioxidant activity, European Food Research and Technology, 235 (2012) 637-645.

[20] A.-L. Gancel, A. Feneuil, O. Acosta, A. M. Perez, F. Vaillant, Impact of industrial processing and storage on major polyphenols and the antioxidant capacity of tropical highland blackberry (Rubus adenotrichus), Food Research International, 44 (7) (2011) 2243-2251.

[21] J. B. Adams, Thermal degradation of anthocyanins with particular reference to the 3-glycosides of cyanidin. I. in acidified aqueous solution at $100{ }^{\circ} \mathrm{C}$, Journal of the Science of Food and Agriculture, 24 (7) (1973) 747-762.

[22] L. Verbeyst, K. Van Crombruggen, I. Van der Plancken, M. Hendrickx, A. Van Loey, Anthocyanin degradation kinetics during thermal and high pressure treatments of raspberries, Journal of Food Engineering, 105 (3) (2011) 513-521.

[23] K. Torskangerpoll, O.M. Andersen, Colour stability of anthocyanins in aqueous solutions at various $\mathrm{pH}$ values, Food Chemistry, 89 (3) (2005) 427-440.

[24] Y. Shinoda, H. Komura, S. Homma, M. Murata, Browning of model orange juice solution: Factors affecting the formation of decomposition products, Bioscience, Biotechnology, and Biochemistry, 69 (11) (2005) 2129-2137.

[25] J. Debicki-Pospisil, T. Lovric, N. Trinajstic, A. Sabljic, Anthocyanin degradation in the presence of furfural and 5-hydroxymethylfurfural, Journal of Food Science, 48 (2) (1983) 411-416.

[26] G. Mazza, R. Brouillard, Recent developments in the stabilization of anthocyanins in food products, Food Chemistry, 25 (3) (1987) 207-225.

[27] A. Kirca, B. Cemeroglu, Degradation kinetics of anthocyanins in blood orange juice and concentrate, Food Chemistry, 81 (4) (2003) 583-587.

[28] N. Harbourne, J.C. Jacquier, D.J. Morgan, J.G. Lyng, Determination of the degradation kinetics of anthocyanins in a model juice system using isothermal and nonisothermal methods, Food Chemistry, 111 (1) (2008) 204208.

[29] W-D. Wang, S-Y. Xu, Degradation kinetics of anthocyanins in blackberry juice and concentrate, Journal of Food Engineering, 82 (3) (2007) 271-275.

[30] M. Dyrby, N. Westergaard, H. Stapelfeldt, Light and heat sensitivity of red cabbage extract in soft drink model 
systems, Food Chemistry, 72 (4) (2001) 431-437.

[31] E. Nikkah, M. Khayamy, R. Heidari, R. Jamee, Effect of sugar treatment on stability of anthocyanin pigments in berries, Journal of Biological Sciences, 7 (8) (2007) 14121417.

[32] V.V. de Rosso, A.Z. Mercadante, Evaluation of colour and stability of anthocyanins from tropical fruits in an isotonic soft drink system, Innovative Food Science and Emerging Technologies, 8 (3) (2007) 347-352.
[33] E.E. Meschter, Effects of carbohydrates and other factors on strawberry products, Journal of Agricultural and Food Chemistry, 1 (8) (1953) 574-579.

Izvod

\section{KINETIKA TERMALNE DEGRADACIJE UKUPNIH POLIFENOLA, FLAVONOIDA, ANTOCIJANA I POJEDINAČNIH ANTOCIJANATOKOM PRIPREME DVE VRSTE DŽEMA OD DIVLJIH KUPINA}

Milena Nikolić, Aleksandra Pavlović, Milan Mitić, Snežana Mitić, Snežana Tošić, Emilija Pecev-Marinković, Jelena Mrmošanin

Univerzitet u Nišu, Prirodno-matematički fakultet, Departman za hemiju, Niš, Srbija

U radu je praćena kinetika termalne degradacije $\left(90,95,100\right.$ i $\left.105^{\circ} \mathrm{C}\right)$ ukupnih polifenola (TP), flavonoida (TF) i antocijana (TA), i ispitana je antioksidativna aktivnost tokom pripreme dve vrste džemova (sa manjim i većim sadržajem šećera) od divljih kupina. Na sadržaj ukupnih polifenola, flavonoida i antocijana, kao i na antioksidativnu aktivnost džemova, značajno utiču temperatura, dužina kuvanja i vrsta džema. Najmanji gubici u sadržaju TP, TF i TA zabeleženi su u džemu sa manjim sadržajem šećera pripremanom na $90{ }^{\circ} \mathrm{C} 5$ minuta, a najveći gubici su u džemu sa većim sadržajem šećera pripremanom na $105^{\circ} \mathrm{C} 30$ minuta. Od identifikovanih pojedinačnih antocijana, u džemu sa manjim sadržajem šećera, cijanidin-3-rutinozid je najstabilniji, dok je cijanidin-3-malonilglukozid najnestabilniji. U džemu sa većim sadržajem šećera, cijanidin-3-rutinozid i cijanidin-3-malonilglukozid su bili relativno ujednačene stabilnosti, dok je cijanidin-3-glukozid bio najnestabilniji. Za opisivanje brzine degradacije ukupnih antocijana tokom pripreme obe vrste džema, korišćene su kinetičke jednačine prvog reda. Izračunate energije aktivacije (Ea) reakcije degradacije ukupnih antocijana, u temperaturnom intervalu od $90^{\circ} \mathrm{C}$ do $105^{\circ} \mathrm{C}$, u džemu sa većim sadržajem šećera i u džemu sa manjim sadržajem šećera su $57,4 \mathrm{~kJ} / \mathrm{mol}$ i $48,0 \mathrm{~kJ} / \mathrm{mol}$. Vreme polu-života, $\mathrm{t}_{1 / 2}$, ukupnih antocijana u džemu sa većim sadržajem šećera je u intervalu od 6,6 do 15,9 minuta, dok je u džemu sa manjim sadržajem šećera u interval od 13,1 do 27,7minuta. Smanjenje sadržaja ukupnih antocijana sa porastom temperature je izraženije u džemu sa većim sadržajem šećera.
(ORIGINALNI NAUČNI RAD) UDK 547.973:664.858:582.712

Ključne reči: antocijani, kinetika degradacije, kupina, džem, ukupni polifenoli, antioksidativna aktivnost 